\title{
A common approach to the role of the judiciary in fostering the common area for criminal justice in the European Union
}

There are about 80,000 national judges in the European Union. This paper ${ }^{1}$ attempts to examine what is needed to help these judges better to discharge their duties and responsibilities in criminal justice within the common area for justice. It is an issue of particular importance in the context of fostering mutual confidence which is a necessary precondition to judges in one Member State readily enforcing judgments of courts of other Member States, as is being more often required of them by the EU treaties and legislation.

In the criminal justice system judges have the ultimate responsibility for ensuring that the interests of the three parties involved in a criminal case - the state, the accused and the alleged victim - are each properly protected within the framework of the national laws established by the Member State and increasingly by the laws of the European Union. The duties and responsibilities of the judiciary primarily lie in interpreting the law and secondly in seeing that the system for the delivery of justice operates effectively in practice in the cases actually before the court. Insufficient attention is paid to the risk that the letter of those laws can effectively be undermined if the judiciary does not exercise these duties and responsibilities.

At the outset, it is convenient to state my conclusions and then explain how I reached them.

1. The judiciary needs a structure that gives it the individual and institutional independence to carry out its duties and responsibilities; the judiciary must be accountable for the discharge of those duties and responsibilities.

2. A structure on its own is not enough. There must be the ethos and other conditions necessary to ensure those duties and responsibilities are fully discharged.

3. The discharge of judicial duties and responsibilities is dependent upon other circumstances. The role of the judiciary in relation to each must not only be examined and clarified, but the judiciary should take a more proactive role in this respect.

4. The discharge of the duties and responsibilities of the judiciary also requires a practical working relationship with the executive and legislative branches of the state.

5. A common approach must be developed in relation to these matters if there is to be mutual confidence between the judiciaries that will enable true protection for the rights of the defendant and victim across Europe.

1 This paper is based on a lecture given on 22 October 2010 at a conference of the University of Luxembourg and the International University Institute of Luxembourg: Criminal Justice in Europe: Challenges, Principles and Perspectives. 


\section{I. \& II. Structure and Ethos}

It is convenient to examine together the first two conclusions - how both structure and ethos are necessary to create that proper degree of independence necessary for the judiciary to discharge its duties and responsibilities. The United Kingdom provides an illustration with which it is convenient to begin.

There was no formal structure of institutional independence in England and Wales until five years ago when the Constitutional Reform Act 2005 was enacted. In practice this did not matter as a very brief overview of the role of the judiciary demonstrates. Judges had been individually independent since the constitutional struggles of the seventeenth century. ${ }^{2}$ Although the judges had no formal structure of institutional independence, as the head of the judiciary was the Lord Chancellor, the living embodiment of the denial of the separation of powers in that he was also a member of the executive and speaker of the legislature, this did not matter. The number of senior judges was very small and they had an informal institutional structure in the three superior courts of common law each headed by a chief justice. Montesquieu was right in seeing through the structures to the ethos.

These senior judges were used not merely to interpreting the law but creating it and devising methods of bringing the other courts of England and Wales within their control. ${ }^{3}$ The criminal law was civilised from its harsh and bloody origins by the judges; crimes were more precisely defined or created and codification resisted as it fettered judicial freedom. They also created soft law - for example, the law governing the interrogation of suspects was devised by the judges in a set of rules known as the Judges' Rules at the request of the police at the beginning of the twentieth century. ${ }^{4}$ Judges were responsible for seeing that the system for the administration of justice operated effectively by having a responsibility for ensuring cases came to trial within a reasonable time. $^{5}$

Judges took a great interest in legislative activities. It is clear from the time of Blackstone and vividly seen during the nineteenth century that they were generally involved in detailed comments on legislation. ${ }^{6}$ They were careful, however, to avoid being engaged in politics. An interesting example can be seen in 1868 when the group were asked to take on the role of deciding parliamentary election disputes. The Chief Justice wrote to the Lord Chancellor expressing the concern of judges on the effect on confidence in the judiciary: ${ }^{7}$

2 The Act of Settlement 1701 guaranteed security of tenure and prevented a reduction in salary.

3 The history is most recently and elegantly traced in the judgment of Laws LJ in R(Cart) $v$ Upper Tribunal [2010] 2 WLR 1012.

4 They originated in a letter in 1909 from Lord Alverstone, Chief Justice, to a Chief Constable who had sought advice when judges had expressed different views as to the warnings that had to be given to a suspect when questioned. The first set of Rules was approved by the judges in 1912: see Practice Note (Judges Rules) [1964] 1 WLR 152.

5 As in any judicial system there were periodic failures: Dickens' Bleak House is a powerful critique of English justice in the mid nineteenth century.

6 I traced this involvement in (2009) 50 Legislacao 277.

7 Letter of 14 February 1868, Parliamentary Papers, 1868. 

in the European Union

"This confidence will speedily be destroyed, if, after the heat and excitement of a contested election, a Judge is to proceed to the scene of recent conflict, while men's passions are still roused, and, in the midst of eager and violent partisans, is to go into all the details of electioneering practices, and to decide on questions of general or individual corruption, not unfrequently supported or resisted by evidence of the most questionable character. The decision of the Judge given under such circumstances will too often fail to secure the respect which judicial decisions command on other occasions. Angry and excited partisans will not be unlikely to question the motives which have led to the judgment. Their sentiments may be echoed by the press. Such is the influence of party conflict, that it is apt to inspire distrust and dislike of whatever interferes with party objects and party triumphs."

It was because of this long established tradition that when, because of various changes that occurred at the end of the twentieth century, formal institutional structures had to be created, ${ }^{8}$ there was little perceptible change. New structures, although essential in changed conditions, would never have worked so well immediately, if it were not for the tradition and ethos that existed.

Before turning to the inter-relationship of structures and ethos in other States of the European Union, I wish to say a little more about the two duties in a European context - interpreting and developing the law and seeing that the system for the delivery of criminal justice operates efficiently. I do that against the background where, first, there is now a common approach to the development of rights set out in the European Convention on Human Rights, particularly in Article 6 and the case law of the Strasbourg Court which has begun to make the Convention more readily applicable. Second, under the roadmap of the Stockholm Programme, there will be EU legislative action to develop procedural rights; this should bring about greater precision in the formulation of the rights that have a direct practical effect on the operation of criminal justice systems. Thirdly, the EU Commission is now in a position to take action to see that these new directives are enacted in the Member States.

\section{Interpreting and developing the law}

The judiciary has two primary roles in interpreting and developing the law. The first aspect is its role in court in applying and interpreting the law to the case before it, developing the law as necessary. For this an organisational framework is essential; at a basic level it is needed to ensure routine matters, such as training, can be properly handled. More importantly, judges need the protection of an institutional framework from time to time when developing and interpreting the law. I do not mind at all being told that a decision of mine is wrong, either by another court or by an academic. For that an institutional framework is not necessary. However, if a judge is called "irresponsible" by a Government minister or accused of being totally out of touch with reality, or caricatured in the media, then he needs that protection. The clearest example of this can be

8 The Lord Chief Justice replaced the Lord Chancellor as Head of the Judiciary of England and Wales and formal structures for appointments and discipline were created by the Constitutional Reform Act 2005; an agreement governing the control of the Court Administration was made in April 2008. 
seen in the attacks by the media that have been made on one of the judges in England $\&$ Wales in his application and development of the law of privacy which the media have perceived as inimical to their interests. This aspect of the national judge's duty under the guidance of the Luxembourg Court is traditionally viewed as his paramount duty.

There is a second aspect of the duty in developing the law - leadership and engagement in relation to sub-legislative and legislative developments. It is vital that judges are engaged, whether at the formal request of the Executive or Legislature (as they are in the UK in institutions such as the Criminal Procedure Rule Committee) or informally, such as in discussions in relation to legislation. It is my own view, and this is a subject to which I shall return, that engagement on a European level is essential.

\section{The effective operation of the system for delivering justice}

The second duty of the judges is to see that the system for delivering justice operates effectively. It is self evident that an institutional structure is needed for the discharge of the duty to see that a system for delivering justice operates effectively. The law can be interpreted and developed so that its application in a case is fair, just and intellectually correct, but it will not serve the needs of the citizens of a state unless there is an effective system that enables justice to be delivered quickly and at reasonable cost. A useful illustration and important to the theme of this paper is the European Arrest Warrant. If its operation is examined, the problems which arise in practice are not really those of legal interpretation, but practical problems in the delivery of justice - proportional use, lack of interpreters, lack of legal aid, long periods of pre-trial detention and occasionally, ill-treatment in custody. Thus, although interesting points of law fall to be decided in the higher courts of Member States and in Luxembourg, the real problems arise from failings in the systems that are meant to deliver justice. Some argue, for example, that long delays in certain states in bringing to trial a person returned under a European Arrest Warrant is a failure by the Executive, but do not judges also bear a significant responsibility in failing to discharge their duty to see that the systems for the delivery of justice are effective?

It can be argued that there is too much concentration on the primary duty -interpreting and developing the law and insufficient attention is paid to the duty to ensure that the system for the delivery of justice is effective. It may be that ensuring that the law is administered effectively is not at all glamorous or those that spend their time in ensuring this are not recognised or remembered. An interesting example can be taken from one of the greatest judges in the history of the United Kingdom - Lord Mansfield. He was Chief Justice of England from 1756 to 1788. The decisions he made, particularly in settling broad principles of commercial law are still studied by students and used by lawyers today. ${ }^{9}$ It is for that he is remembered. However, his achievement ${ }^{10}$ in reforming procedure and insisting that people dealt with the real issues in the case rather than deciding technical points is work which has largely been forgotten. The judiciary has

9 Carter v Boehm (1766) 3 Burrow 1905 - a case setting out the duty of disclosure in contracts of insurance decided in the context of the operation of the British East India Company in its rivalry with the French.

10 Fifoot, Lord Mansfield, Oxford, 1936, pp 52-81. 
often accorded too little attention to the more prosaic aspect of judicial work in ensuring that cases are promptly dealt with at the least possible cost and that the courts operate efficiently to deliver real justice in cases. It is easy for judges to favour what can readily be seen as the more glamorous and intellectually interesting work of deciding interesting points of law and refining the jurisprudence.

\section{Accountability}

But if the judiciary is to exercise this degree of responsibility, what is its accountability? It is my experience that judges do not find the discussion of accountability an easy subject and it is certainly another topic which has been insufficiently addressed.

One aspect of accountability can readily be dealt with. Where money is entrusted to the judiciary to run the court administration or for training there has to be accountability for the way in which the money is spent; the judiciary is no different to any other part of the state in being required to show that it spends money wisely and carefully. That can easily be dealt with by those who are employed to administer within the judiciary being made accountable for the way in which the money is spent.

More difficult, however, is accountability for the operation of the judicial system, by which I mean matters such as delays in particular courts, slow and costly procedural steps, a lack of effective case management, or judges taking too long to complete judgments. Two terms have commonly been used to describe accountability - explanatory accountability and sacrificial accountability. The first relates to a requirement that a body explains what it does in terms that its work is open and transparent; the second requires a resignation or dismissal of the person in charge, if there are failures in matters for which there is accountability. It is the former, not the latter, that is applicable to the operation of a judicial system. It depends on transparency. Judges must be prepared to accept openly that there may be problems in the effective operation of the judicial system and be prepared to explain why the problem has arisen, what has been done about it and why it will not happen again. Experience of any judicial system shows that work in a particular area can suddenly grow and, through no fault of anyone, the case load of a court becomes such that unacceptable delays occur. As is the practice in some courts, explanations should openly be given as to how this has arisen and the steps being taken to remedy it (or the inability to take those steps due to financial or other reasons). Delays and problems should never be swept under the carpet.

There is a third aspect of the activity of the judicial branch of the State where the issue of accountability is far more difficult. Traditionally the view has been taken that a judge is accountable for his judicial decisions by making that decision in open court and in public with the right of the litigants to appeal. But, as the scope of judicial work extends, the question is more than occasionally being asked about the accountability of the highest court in a State or a Federal Union for decisions it makes. This is a topic outside the scope of this paper. 


\section{The governance necessary for institutional independence}

If a branch of the state is to be invested with these functions, then self-evidently it needs a structure to ensure proper governance. Traditionally where judges accepted responsibility for the operation of the system, the structure was essentially hierarchical. However, it is now appreciated that this is a task not best performed through a hierarchical system, dependent as it is on control through the judicial hierarchy. Many have therefore been attracted in Europe to using the institution of Judicial Councils to perform this task. Earlier commentators have looked at what has been described as "the Southern European model" (such as that in Itlay) and "the Northern European model" (such as that in the Netherlands). ${ }^{11}$ However, the picture is much more complicated, particularly with the developments in the east of Europe and in the candidate States. The modern issue is not, in my view, a choice between which model of Council to develop but the choice between the best arrangements for the governance and proper administration of functions which fall within the domain of the judicial branch of the State. These functions are common to every judicial system and are as follows:

a) Operating a fair and efficient system for the delivery of justice on the resources available; ensuring that quality is not suborned to efficiency.

b) The mechanisms for appointment, promotion and appraisal or evaluation.

c) The mechanism for discipline

d)Training

e) Relations with the media.

Space does not permit an extensive discussion of these issues, but it is clear that, apart from the first, there is an absolute need for these functions to be performed independently of the executive and legislative branches of government. As to the first, the view is taken in some states that court administration is best carried out for the judiciary by the executive branch of the state. It is not a view with which I agree because, as I fear many will learn when resources have tightened, it is control over the resources and their efficient allocation that is best left to an accountable judiciary. ${ }^{12}$

\section{Structures without ethos}

It is apparent to any observer, without the need to identify a particular state, that a law can provide that a judge be independent, but that means nothing unless the other branches of the state respect that independence in practice and a judge acts independently. Similarly a judiciary can be provided with a structure for the protection of its independence and its governance which is perfect on paper, but it will not operate to protect the independence of the judiciary unless it has the necessary ethos of independence. One of the tasks that the judiciaries of the several states of the EU has is to ensure that that ethos is developed and maintained in each of the existing Member States; this is a task which

11 See for example: Global Best Practices: Judicial Councils - lessons learned from Europe and Latin America, IFES Rule of Law White Paper Series, Autheman \& Elena, 2004; Councils for the Judiciary in the EU, Voermans \& Albers, 2002.

12 The 2010 Barnard's Inn Reading by Lord Hope: The Creation of the Supreme Court- was it worth it? contains a useful illustration of such a concern. 
is novel and will require much thought, for it will require judges to take positions of principle about how a judiciary or a judicial system in another Member State operates. Similarly it will be important for candidate states to show that they have not merely a structure for the effective and independent administration of justice, but that they have the ethos of independence as well. Uncomfortable though these issues are (as my own experience confirms), they are not issues to which a blind eye can be turned.

\section{Interdependence}

The proper organisation and provision of adequate resources to the judicial branch of the state cannot of itself be enough to enable judges to perform the duties to which I have referred. There are numerous dependencies. In the area of criminal justice, four are of particular importance. In each much more needs to be done by the judiciary to ensure that proper arrangements are in place so that the necessary support is provided.

\section{The accountability of prosecutors and their relationship to judges}

The role of a prosecutor in a criminal justice system is central to its proper operation. The need for the fairness and impartiality of the prosecutor can be seen most clearly by an examination of some of the tasks that are entrusted to the prosecutor.

First, there is the discretion to prosecute which is recognised in many states. Although in some states the view is taken that every crime must be prosecuted, given the multiplicity of offences in the modern state, it is in reality impossible for any system to cope with each infraction of the criminal law if the duty to prosecute or punish is in fact invariably invoked; the operation of the European Arrest Warrant would simply break down if every prosecutor was to apply for an arrest warrant in all cases where there was a cross-border element and which was within the scope of the legislation. As a prosecutor has therefore to exercise a discretion, even in legal systems which do not formally recognise it, it is necessary to have clear rules as to the exercise and control over the exercise of the discretion. It may be easy, of course, to say that a prosecutor should not prosecute minor infractions but minor infractions are not always insignificant as, for example, when the offender is a political figure of some importance. More difficult are cases where the public sees a prosecution as being inhumane in certain circumstances, such as cases of failed suicide where someone is suffering from a terminal illness of great pain or where an elderly husband has, through inadvertence whilst driving, killed his wife of many years. Again there are cases where the victim considers that a crime should be prosecuted and is critical of the prosecutor for failing to act; this is leading to calls for the law to allow private prosecutions. It is clear that these issues need to be addressed in such a way that there is a common approach that takes into account the different national systems. Should prosecutorial systems provide for internal routes of appeal? What degree of judicial control should be exercised over the exercise of the discretion?

Second, in recent years, as court systems have not adapted sufficiently to deal with the mass of cases of minor infractions brought before them, there has been across the EU a very significant rise in the use of out of court penalties for offences other than 
those relating to the use of the car. In some states the power to impose these penalties has been left to the police and in others to the prosecutor; some states have adopted elemental grid systems to guide the application of penalties in a manner akin to the sentencing grids used by the Federal Courts in some states in the United States. Has sufficient thought been given to formulation of policies prosecutors should adopt in relation to the exercise of the power to punish? How is control to be exercised over actual decisions? How is the operation of such a system to be made transparent? It is axiomatic that a court cannot punish unless it does so in open court where the media can report what is happening, but what of prosecutorial decisions? By their very nature these are made in private and the penalties not administered in public.

Third is the increasingly important regime of disclosure of the prosecution papers, exculpatory material and the case file. As work done in relation to the proposal to include disclosure within the draft directive on the right to information has revealed, even apparently similar regimes differ. The role of the prosecutor is, however, becoming increasingly important in many states in ensuring that the duty of disclosure is properly discharged; in relation to the gathering of covert information, this can be a difficult $\operatorname{task}^{13}$ and no doubt even more difficult where secret intelligence services have been involved in surveillance or gathering information.

It is obvious from these illustrations how dependent a judicial system is for the delivery of justice in criminal cases on the need to ensure that prosecutors are independent of the executive and legislative and that the relationship between prosecutors and judges is clearly defined. An important step was taken by the Consultative Council of European Judges and Consultative Council of Prosecutors in their 2009 opinion, ${ }^{14}$ but this did not significantly address the issue of governance and accountability which as each of the illustrations indicate, gives rise to difficult issues that require resolution. The judiciary has a vital interest in ensuring that this is done.

\section{The quality of defence representation}

However much a judge may seek to do justice in a criminal case, a judge cannot do so if a defendant is not properly represented. The right to legal representation is now firmly established and its parameters well understood in the light of Salduz v Turkey. ${ }^{15}$ Its importance is well known, for it is the lawyer who will raise the issues that enable the judge to move the law forward.

Most defendants have some form of legal representation provided at the cost of the state; in most states it is provided by persons who are not employees of the state. Where the state pays for the provision in this way, the state needs to ensure that the legal representation is of sufficient quality. It would be unthinkable if patients were treated by medical practitioners whose ability to practice was not regularly assessed, but the quality standards for lawyers are at best rudimentary after initial qualification and controls over the quality of lawyers funded by the state are too basic. Although the judiciary cannot express views about the level of finance required to obtain good quality repre-

13 A recent example is Natunen $v$ Finland (2009) 49 EHHR 32.

14 Opinion No 12 of the CCJE and No 4 of the CCPE.

15 (2009) 49 EHRR 19. 
sentation, it has again a vital interest in ensuring that there are regimes that maintain and improve the quality of defence representatives.

\section{The role of forensic scientists}

It is quite clear that advances in forensic science are having a very significant impact upon the detection of crime and in proving guilt or establishing innocence at trial. Whereas at the beginning of the twentieth century fingerprint evidence was seen to be a significant advance, the development of DNA in the past 20 years has enabled minute quantities to be used in proving a case against a defendant. ${ }^{16}$

It is clear that for justice to be done in criminal cases, there must be control over the way in which such evidence is gathered, analysed and put before the court. The last is particularly important in systems where there is lay participation in determining guilt, as experience has shown that very substantial weight can be placed upon expert evidence given by a scientist, as he is often seen in quite a different category to witnesses of fact who may have motives to distort the truth. However, experience has also shown that scientists can make serious errors and when these are subsequently exposed considerable damage is done to confidence in the administration of justice.

Thus, in a number of cases the effective operation of the criminal justice system is dependent upon an important area which is not easily susceptible to control by those outside the scientific community. However, it is important that judges do exercise a degree of control. ${ }^{17}$ The traditional method has been to look at the reliability of the science and consider whether it is sufficiently reliable for expert opinions to be based on it. However, with increasingly rapid advances in forensic science, is this still maintainable? It is interesting to note the development of very close co-operation that is arising across the world between the professionals in forensic science. ${ }^{18}$ But have the judges matched this? I think the answer is clearly no; again this is an area where a common approach is needed for the effective operation of the criminal justice system.

I will return to the fourth example of dependency - the need for academic study and the role of the judiciary in this.

\section{Relations with the executive and parliament}

There is a long tradition in the United Kingdom of close involvement between the legislative, executive and judicial branches of the state. It dates back to times where noone would have perceived any separation of powers, but from the time in the eighteenth century that the need for such separation was clearly appreciated, the three branches of

16 Analysis of low template DNA now enables quantities of less than 100 picograms to be measured; a picogram is one million millionths of a gram $\left(10^{-12}\right)$ roughly equivalent to a ten millionth of a grain of salt.

17 An early example is fingerprint evidence - see $R v$ Castleton (1910) 3 Cr App R 74 and the history set out in $R v$ Buckley (30 April 1999).

18 See for example the practice in footwear mark evidence set out in $R v T$ [2010] EWCA Crim 2439. 
the State in the United Kingdom have, within their respective spheres worked closely together. I have written elsewhere about how this works in practice in England and Wales. ${ }^{19}$

Judges across Europe frequently complain about the mass of poorly drafted legislation both that enacted by their national legislatures and that which comes from Brussels. ${ }^{20}$ Poorly drafted legislation and an excess of legislation self evidently defeats the proper administration of justice by adding to its complexity and expense. But is enough done by the judiciary to try and deal with this?

The answer is no. The dividing line between what it is proper for a judge to do and that which it is not is easy to express. When the legislature or executive proposes a policy which affects the administration of justice, a judge can and should in my view comment on the alternative technical solutions proposed to implement that policy and on the perceived effects of a policy (both good, bad and neutral). What a judge cannot do is to advocate the adoption or rejection of a policy - that is for the legislature or the executive. A judge also can and should comment on drafting, particularly by pointing out where it is over complex or does not achieve what the draftsman is seeking.

In the European Union, it has been my own experience that there has been a very considerable reticence of judicial involvement in this activity. It is, however, being slowly recognised that the judiciary has an important role to play and views are now being expressed on draft legislation and policy. I very much hope that the judiciary will gradually lose its reticence and the Parliament and the Commission will see the real value of working together in this way, each respecting the different roles of the other and in particular the limits of what the judiciary can do.

\section{Conclusion}

There is, in my view, much more in common in our criminal justice systems across Europe than there is in difference. In the United Kingdom it is a commonplace to refer to the systems of continental Europe as inquisitorial and the system in the United Kingdom as being radically different as it is adversarial. It is true, of course, that the historic origins point to that division, but under various influences, perhaps the most important of which is the ECHR, our systems have come much more close together. For example, in the work that I have recently been doing in relation to the treatment of alleged victims of crime in the courts, it is clear that, despite the differences, the basic approach of each judge should be the same.

Given that we have so much in common amongst the judiciaries of the European Union and that the issues are very similar as I have endeavoured to explain, how important is it that a common approach be developed in the area of criminal justice to the issues I have raised? In my view it is essential. A decision was made, most clearly seen in the context of the European Arrest Warrant to move to a system of returning citizens for trial in another Member State which presupposed that each criminal justice system operated in the same effective manner to protect the rights of defendants and victims. It

19 See the paper in Legislacao to which I have referred.

20 See Report on the Role of the National Judge in the European Judicial System, European Parliament, 2008. 
is plain, however, that the systems do not - it is well known, for example, that some systems have unacceptable periods of pre-trial delay. It is inevitable therefore that some politicians have begun to question the European Arrest Warrant on the basis that it should not operate in the simple manner in which it does operate until there is a much greater uniformity of standards. It is put simply that the cart has been put before the horse. Uniform standards should have been a pre-condition to the European Arrest Warrant.

It is, of course, in part the responsibility of the executive and legislature to take action to bring about changes in judicial systems that fall short of what should be acceptable in a common area for justice. However, each national judiciary also has a responsibility for the operation of its criminal justice system as I have endeavoured to explain, but as is apparent not enough is being done by the judiciary in this respect with a real risk to the development of the common area for justice. The politicians may have put the cart before the horse, but the judges have a responsibility within their respective states to put matters right.

Much therefore could and should be done by the judiciary in the discharge of its duties and responsibilities. Take for example, the ill-treatment of prisoners to which I have referred; the Strasbourg Court has made clear the duties of a court which orders detention to see that the provisions for detention are compliant with the Convention, ${ }^{21}$ but how often do courts in fact discharge those duties? The European Network of the Councils for the Judiciary has as its core objective enabling the timely and effective delivery of justice for the benefit of all across the European Union. ${ }^{22}$ This is but one voice. I have no doubt that in the area of criminal justice, there is a real need for judges to join with practitioners and academics in studying these issues and promoting practical solutions. In my remarks at the conference, I expressed the hope that this will be taken forward by the University of Luxembourg, for this is the fourth key dependency to which I earlier referred. The judiciary must discharge the duties and responsibilities to which I have referred, but it cannot do so unaided.

21 Price v UK (APPN 33394/96, 10 October 2001).

22 Its 2009 Bucharest Resolution spelt this out. 